MARLENA PLEBAŃSKA

Uniwersytet Warszawski

\title{
Stan cyfryzacji polskich szkół na podstawie badania "Polska szkoła w dobie cyfryzacji. Diagnoza 2017" w kontekście potrzeby wdrożenia nauczania w modelu STEAM
}

\begin{abstract}
Marlena Plebańska, Stan cyfryzacji polskich szkót na podstawie badania "Polska szkota $w$ dobie cyfryzacji. Diagnoza 2017" w kontekście potrzeby wdrożenia nauczania w modelu STEAM [Digitisation of Polish Schools Based on the "Polish School in the Digitisation Era. The 2017 Diagnosis" Survey in the Context of the Necessity of Implementing the STEAM Model of Teaching]. Interdyscyplinarne Konteksty Pedagogiki Specjalnej, nr 23, Poznań 2018. Pp. 59-75. Adam Mickiewicz University Press. ISSN 2300-391X. DOI: https://doi.org/10.14746/ikps.2018.23.03
\end{abstract}

The author of the paper presents the concept of teaching in the STEAM model in relation to the necessity of building competence of tomorrow among pupils of primary schools and even preschools. The author sets forth the status of digitisation of Polish schools in the light of the most extensive Polish digitisation survey: the 2017 Digital Diagnosis. The author primarily discusses the conclusions from studies pertaining to the status of digitisation of the Polish schools in the context of implementation of the STEAM model as a concept for developing competence of tomorrow. Results of studies conducted in June 2017 among pupils, parents and teachers are presented. The study was prepared and conducted by a team of researchers/academic employees of the Faculty of Education at the University of Warsaw in cooperation with PCG Edukacja under the supervision of the author of this paper. The study encompassed 100,129 respondents from primary schools, middle schools, high schools, technical schools and vocational schools from all provinces in Poland. The full report presenting the study results is available on website: https://www. 
librus.pl/doradca-dyrektora/informacje-prawne/organizacja-pracy-szkoly/stan-cyfry zacji-polskich-szkol-ku-refleksji-raport-2017/

KEY WORDS: STEAM, competence of tomorrow, digital education technologies, digital school

\section{Kompetencje przyszłości}

Określając kształt współczesnej edukacji, często zadajemy sobie pytania: jakim kierunku powinno być skierowane współczesne kształcenie? jakich pracowników będzie potrzebował rynek pracy? $\mathrm{w}$ jakie kompetencje powinni zostać wyposażeni pracownicy przyszłości? na jakim etapie kształcenia powinniśmy rozpocząć kształcenie kompetencji przyszłości? jaki wpływ mają trendy w gospodarce światowej na kształcenie najmłodszych? To oczywiście tylko przykładowe pytania, których moglibyśmy skonstruować setki, zdecydowanie mocno wskazują one jednak na istotny wpływ pomiędzy rozwojem gospodarczym a edukacją. Współczesna gospodarka to stała zmiana, intensywny rozwój cyfryzacji oraz postępująca robotyzacja, rozwój sztucznej inteligencji, jak również olbrzymi nacisk na rozwój kompetencji społecznych, takich jak np. praca projektowa, praca $\mathrm{w}$ zespołach wirtualnych czy praca $\mathrm{w}$ środowiskach multikulturowych. Istnieje wiele opracowań, które próbują wskazać, w jakie kompetencje powinien zostać wyposażony współczesny uczeń. Jednym $\mathrm{z}$ takich opracowań jest raport Future Work Skills 2020, opracowany przez The Institute for the Future (IFTF), który wskazuje umiejętności zawodowe przyszłości - 2020. Badanie, które jest podstawą raportu, realizowane było w 2011 r. przez badaczy IFTF i Uniwersytetu Phenix (University of Phoenix Research Institute). Raport wskazuje sześć głównych czynników wpływających na rozwój społeczeństwa w najbliższych latach, takich jak: ekstremalna długowieczność, rozwój inteligentnych maszyn i systemów, obliczalny świat, nowy ekosystem mediów, super struktury organizacyjne, globalnie połączony świat. Raport przedstawia również 10 kompetencji przyszłości, 
w które powinni być wyposażeni uczniowie, a mianowicie: kompetencje międzykulturowe, praca w szumie, wnioskowanie, inteligencja emocjonalna, współpraca w wirtualnym środowisku, przetwarzanie danych, sprawność adaptacyjna, myślenie projektowe, międzydyscyplinarność, kompetencje cyfrowe. Z kolei publikacja Miejsce pracy w 2020 r.: Jak innowacyjne firmy przyciagaja dziś pracowników jutra, wspieraja ich rozwój $i$ zatrzymują, poświęcona tworzeniu i wdrażaniu długo- i średniofalowych strategii w obszarze zarządzania zasobami ludzkimi, przedstawia listę najważniejszych czynników wpływających na zmiany. Autorki opisują $10 \mathrm{z}$ nich:

1. Zmiana demograficzna - pod koniec obecnego dziesięciolecia, a więc ok. 2020 r., po raz pierwszy w historii pięć pokoleń pracowników może pracować obok siebie w jednym zakładzie pracy. Autorki określają te generacje następująco: tradycjonaliści (urodzeni przed 1946 r.), dzieci powojennego boomu (tzw. baby boomers urodzeni w latach 1946-1964), generacja X (urodzeni w latach 1965-1976), pokolenie ostatniego dwudziestolecia XX w. (urodzeni w latach 1977-1997) oraz generacja 2020 (urodzeni po 1997 r.).

2. Gospodarka oparta na wiedzy - autorki wyjaśniają, że w 2010 r. firmy w USA zatrudniały dwa razy częściej pracowników zdolnych do kreatywnego myślenia, niż tych, którzy jedynie powielają typowe działania. Jako "gospodarkę opartą na wiedzy" w obszarze HR autorki rozumieją przede wszystkim elastyczność pracodawcy i pracownika w dostosowaniu się do zachodzących zmian, umiejętność zdobywania nowych kwalifikacji oraz jednoczesny rozwój umiejętności „twardych” oraz interpersonalnych.

3. Globalizacja - łatwość outsourcingu i zatrudniana na odległość powoduje zmianę lokalnej oraz globalnej struktury zatrudnienia. Czynnik ten autorki ilustrują przykładami firm IBM i Procter\&Gamble.

4. Cyfrowe miejsce pracy - cyfrowa informacja w życiu zawodowym i prywatnym odgrywa coraz bardziej znaczącą rolę. Pojawiają się nowe platformy informatyczne i protokoły, zy- 
skują na znaczeniu kwestie zabezpieczenia danych osobowych i firmowych.

5. Wszechobecność technologii mobilnych - rośnie nacisk na samodzielne poszukiwanie przydatnych informacji oraz nawiązywanie i podtrzymywanie kontaktów z dowolnego miejsca na ziemi. Cytowane są przypadki Bank of America, Invitrogen i Wachowia jako firm wdrażających platformy do prowadzenia szkoleń na odległość przy wykorzystaniu smartfonów.

6. Kultura łączności - za pomocą tego terminu autorki określają potrzebę stałego podłączenia do internetu $\mathrm{w}$ celu wywiązywania się z obowiązków służbowych, realizacji potrzeb społecznych, poszukiwania informacji i podnoszenia kompetencji.

7. Społeczeństwo partycypacji - tym mianem w książce określono społeczeństwo, w którym kwitnie współpraca oraz dzielenie się wiedzą.

8. Społecznościowe uczenie się (ang. social learning) - to proces silnie zintegrowany z rozwojem nowych technologii, takich jak komunikatory peer-to-peer, portale społecznościowe, wideoblogi czy dedykowane platformy do e-learningu.

9. Społeczna odpowiedzialność biznesu (CSR) - odzwierciadla coraz większą wagę pozafinansowego oddziaływania przedsiębiorstwa na społeczeństwo.

10. Nowe pokolenia $\mathrm{w}$ pracy - to pracownicy, którzy oczekują zupełnie innego sposobu integracji $\mathrm{w}$ pracy niż pokolenia poprzednie ${ }^{1}$.

Z kolei Światowe Forum Ekonomiczne (World Economic Forum) zbudowało ranking kompetencji, na której znalazły się następujące kompetencje opracowane w Polsce przez portal MonsterPolska.pl.

Kompleksowe rozwiązywanie problemów - niezmiennie znajduje się na pierwszym miejscu listy. To umiejętność analizowania wielu danych i informacji, podejmowania decyzji i wdrażania rozwiązań. W przyszłości jej znaczenie może spadać w sektorach moc-

${ }^{1}$ N. Vitorović, Miejsce pracy w 2020 r.: Jak innowacyjne firmy przyciagaja dziś pracowników jutra, wspierają ich rozwój i zatrzymuja, http://www.pi.gov.pl/PARP/chap ter_86199.asp?soid=C8A49387D2884B7B80AA8E3099BE0199 [dostęp: 20.12.2018]. 
niej zautomatyzowanych, takich jak: infrastruktura czy energetyka, wzrośnie jednak w usługach i informatyce.

Krytyczne myślenie - umiejętność logicznego rozumowania i chłodnej analizy zyskuje na znaczeniu. W czasach zaawansowanych technologii i skomplikowanych rozwiązań osoba, która potrafi krytycznie podejść do sytuacji i ocenić ją będzie na wagę złota.

Kreatywność - awansowała z dziesiątego miejsca w rankingu. To będzie umiejętność absolutnie kluczowa nie tylko w branżach, z którymi dziś się kojarzy - jak media czy rozrywka - ale wszędzie. Praca będzie czekać na osoby myślące niestandardowo, bo to one będą w stanie wymyślać nowe usługi i produkty, w szybko zmieniających się czasach.

Zarządzanie ludźmi - ta i kolejna cecha pokazują, że jeszcze ważniejsza na rynku zatrudnienia będzie praca zespołowa. Pracodawcy będą potrzebować liderów - empatycznych, panujących nad mową ciała i umiejących jasno komunikować się z ludźmi.

Współpraca z innymi - raport definiuje ją jako „umiejętność dostosowywania swoich decyzji i zachowań do tego, jak zachowują się inni". Chodzi więc o pewną elastyczność, nieupieranie się przy swoim zdaniu oraz otwartość na współpracowników.

Inteligencja emocjonalna - to nowość w rankingu. Badania od dawna pokazują, że im wyższa inteligencja emocjonalna, tym wyższa produktywność pracownika. Osoba z takimi kompetencjami potrafi rozpoznawać i nazywać swoje emocje i emocje innych. Potrafi tym samym łatwiej rozwiązywać konflikty i rozładowywać napięcie.

Wnioskowanie i podejmowanie decyzji - pracownik $2020 \mathrm{r}$. musi być samodzielny. Czekanie, aż ktoś załatwi sprawę za niego, nie jest dobrą strategią. Praca w przyszłości będzie wymagała umiejętności szybkiego podejmowania trudnych decyzji.

Zorientowanie na usługi - to, potocznie mówiąc, bycie frontem do klienta. Pracownik skupiony na tym, by pomóc innym, będzie poszukiwany na rynku. Chodzi tu zarówno o pracę w zespole, jak i z klientem.

Negocjacje - bezkonfliktowe rozwiązywanie problemów oraz umiejętność godzenia różnych poglądów i stanowisk spadła w zestawieniu Światowego Forum Ekonomicznego, ale ciągle się liczy. 
Elastyczność poznawcza - zakłada umiejętność znajdowania i łączenia różnych pomysłów, idei i danych. Zdolność widzenia połączeń między na pozór różnymi rzeczami gwarantuje firmom rozwój. Praca przyszłości będzie w dużej mierze oparta na wybieraniu najlepszych z tysięcy pomysłów ${ }^{2}$.

Przedstawione powyżej przykłady zdefiniowania zarówno czynników wpływających na zmianę trendów rynku pracy, jak i próby definiowania kompetencji przyszłości niezależnie od przyjętej klasyfikacji mocno wskazują na fakt, iż dwie główne grupy kompetencji, które będą niezbędne obecnym uczniom w przyszłości to kompetencje społeczne oraz kompetencje cyfrowe.

\section{STEAM, czyli jak kształcić kompetencje przyszłości?}

STEAM to sposób kształcenia znany na świecie od kilku lat, skoncentrowany na tym, aby zaspokoić prawdziwe potrzeby gospodarki XXI w. poprzez rozwój kompetencji przyszłości. STEAM to podejście do uczenia się, które stawia na naukę projektową konsolidującą pięć kluczowych bloków tematycznych naukę, technologię, inżynierię, sztukę i matematykę. STEAM ukierunkowany jest na kształcenie uczniów, którzy w efekcie realizacji STEAM-owych projektów potrafią myśleć w sposób innowacyjny, niestandardowy, którzy podejmują rozważne ryzyko, angażują się w eksperymentalne uczenie się, twórcze rozwiązywanie problemów, podejmują współpracę i aktywnie uczestniczą w procesach twórczych.

Filozofia STEAM odzwierciedla koncepcje:

STEAM = Science \& Technology interpretowane przez

Engineering \& the Arts, bazujące na Mathematica

STEAM to inicjatywa edukacyjna stworzona przez Rhode Island School of Design, która dodaje sztuki do oryginalnej struktury

2 MonsterPolska.pl, Kompetencje przyszłości - to warto umieć, żeby czuć się bezpiecznie na rynku pracy, https://sukcespisanyszminka.pl/kompetencje-przyszlosci/ [dostęp: 20.12.2018]. 
STEM. Według szkoły projektowania w Rhode Island: „celem jest wspieranie prawdziwej innowacji, która łączy się z połączeniem umysłu naukowca lub technologa z koncepcją artysty lub projektanta". Dodanie sztuki do pierwotnej koncepcji STEM jest ważne ponieważ kierunkuje procesy poznawania oraz tworzenia w kierunku naturalnym oraz angażuje $\mathrm{w}$ proces uczenia się wszelkie możliwości ucznia oraz cały jego mózg. Jak widać na rysunku przedstawionym poniżej pierwotny model STEM wykorzystywał tylko lewą półkulę mózgu odpowiadającą za myślenie i rozumienie, logiczne myślenie, procesy analityczne, obliczenia matematyczna, rozpoznawanie przedmiotów za pomocą dotyku, pisanie, czyli cztery obszary $\mathrm{z}$ naszego modelu (STEM), dopiero uzupełnienie modelu o literę A oznaczającą obszar sztuki wprowadziło do modelu wykorzystanie prawej półkuli mózgu odpowiadającej za myślenie abstrakcyjne, kierowanie się intuicją, bycie twórczym i kreatywnym, wymyślanie nietypowych rzeczy, wyobraźnię przestrzenną czy bycie artystą.

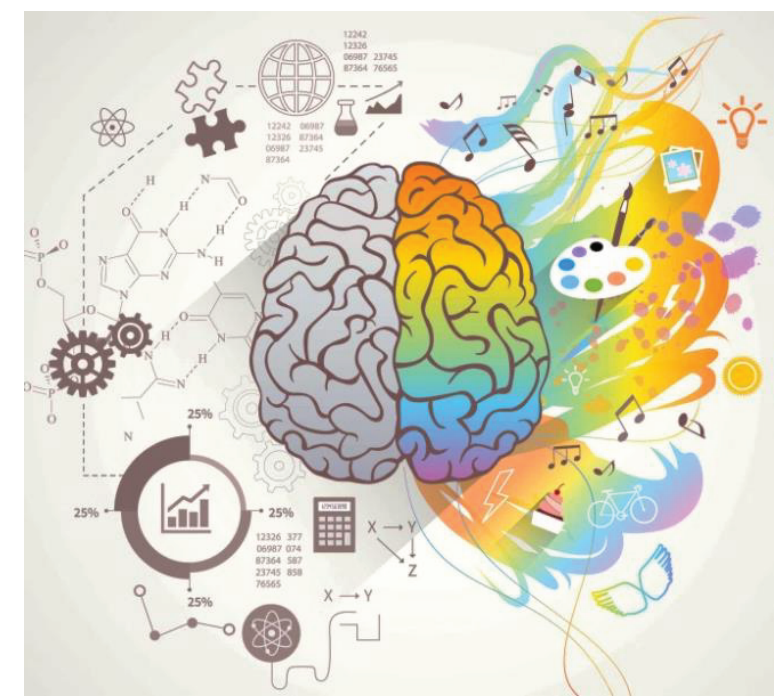

Rys. 1. Mózg aktywacja przy pracy w modelu STEAM Źródło: https://www.bricks4kidz.com.au/sydney-miranda/steam/ [dostęp: 20.12.2018] 
Zatem dopiero pełny model STEAM daje możliwość wykorzystani pełnego potencjału uczniów oraz kształtowania kompetencji przyszłości ${ }^{3}$. STEAM jest adekwatny dla każdego poziomu nauczania z powodzeniem może być realizowany przez zarówno na etapie edukacji przedszkolnej, na etapie szkoły podstawowej, szkoły średniej oraz w kształceniu akademickim. Na świecie projekty STEAM najczęściej stosowane są $\mathrm{w}$ szkołach podstawowych oraz $\mathrm{w}$ szkołach średnich. Bardzo wiele szkół brytyjskich korzysta z modelu STEAM, realizując ciekawe projekty, jak np. system projektowania karmienia ptaków w szkolnych ogrodach czy system nawadniania roślin. Polskie szkoły również wdrażają projekty STEAM, a pierwsze przykłady można dostrzec np. w Szkole Podstawowej numer 6 we Wrześni czy w Zespole szkół numer 6 w Jastrzębiu Zdrój. O możliwościach realizacji projektów STEAM $w$ dużej mierze przesądza infrastruktura technologiczna polskich placówek oraz poziom przygotowania nauczycieli do ich realizacji. O tym, jak przygotowane są polskie szkoły do realizacji innowacyjnej edukacji z wykorzystaniem technologii cyfrowych, możemy przekonać się poprzez analizę wyników największego polskiego badania stanu cyfryzacji polskich szkół „Polska szkoła w dobie cyfryzacji. Diagnoza 2017”.

\section{Czy Polska Szkoła jest gotowa na wdrożenie innowacyjnego kształcenia kompetencji przyszłości? - Wyniki badania "Polska szkoła w dobie cyfryzacji. Diagnoza 2017"}

Poniżej przedstawione zostały wybrane zagadnienia $\mathrm{z}$ badania „Polska szkoła w dobie cyfryzacji. Diagnoza 2017" prezentujące stan cyfryzacji polskich szkół, a co za tym idzie, poziom przygotowania ich do wdrożenia innowacyjnych metod kształcenia budujących kompetencje przyszłości takich jak STEAM

${ }^{3}$ M. Plebańska, STEAM - edukacja przyszłości, „Mazowiecki Kwartalnik Edukacyjny Meritum” 2018, nr 4(51) 2018, s. 2-7. 


\section{Poziom cyfryzacji szkół}

50\% uczniów biorących udział w badaniu deklaruje, że w ich szkole nie są stosowane żadne cyfrowe technologie. $50 \%$ jest zdania, że multimedialne pomoce stosowane są $\mathrm{w}$ procesie dydaktycznym, w którym uczestniczą (rys. 2). Nauczyciele oceniają efektywność zajęć z wykorzystaniem cyfrowych technologii na poziomie dobrym ok. $48 \%$ i bardzo dobrym $23 \%$, argumentują taki stan rzeczy faktem, iż cyfrowe technologie najczęściej stanowią dla uczniów atrakcje, element urozmaicenia, wzbogacenia zajęć. Nauczyciele twierdzą również, iż uczniowie traktują wykorzystanie technologii cyfrowych nie do końca poważnie, a raczej jako materiał uzupełniający, wpierający. Zatem jeśli chodzi o zwiększenia atrakcyjności zajęć dydaktycznych, ten materiał sprawdza się, jeśli zaś mówimy już o atrakcyjności, korelacja nie jest już taka oczywista.

Zdaniem nauczycieli stosowanie nowoczesnych technologii na zajęciach jest zdecydowanie powszechniejsze. 90\% nauczycieli twierdzi, że używa nowoczesnych technologii w procesie dydaktycznym.

Nieliczna grupa ( $10 \%$ wszystkich respondentów), która nie stosuje zasobów cyfrowych $\mathrm{w}$ pracy $\mathrm{z}$ uczniami, najprawdopodobniej ma trudności sprzętowe czy też techniczne $\mathrm{z}$ dostępem do internetu.

Czy w Twojej szkole stosujecie cyfrowe technologie edukacyjne, np. korzystacie z komputerów, tabletów, robotów, cyfrowych podręczników?

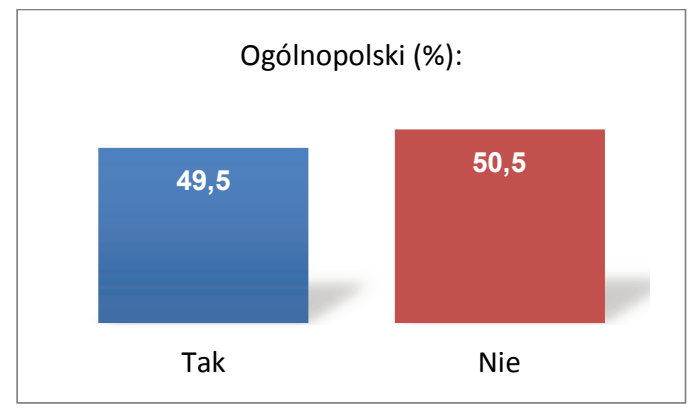

Rys. 2. Wykorzystanie technologii cyfrowych w szkołach Źródło: Raport Polska szkoła w dobie cyfryzacji. Diagnoza 2017 
Niepokojący jest jednak rozdźwięk między odpowiedziami nauczycieli i uczniów, sięgający tu około $40 \%$. Na taki wynik odpowiedzi prawdopodobnie ma wpływ wiedza nauczycieli, którzy zdają sobie sprawę, jak powinny wyglądać zajęcia z zastosowaniem technologii cyfrowych, a jak wyglądają. Nauczyciele mają świadomość tego, jakie czynniki wpływają na efektywność zajęć i jeśli ich możliwości w szkole są ograniczone, mogą prowadzić zajęcia w ograniczonym wymiarze.

\section{Czy w Twojej opinii cyfrowe technologie edukacyjne wspierają edukację dzieci i młodzieży?}

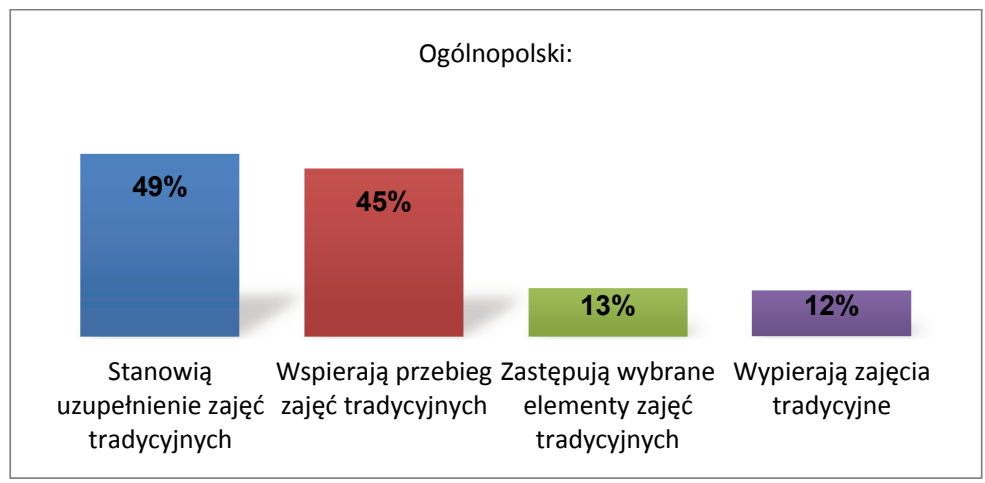

Rys. 3. Wykorzystanie w szkołach technologii cyfrowych w opinii rodziców Źródło: Raport Polska szkoła w dobie cyfryzacji. Diagnoza 2017

Z kolei rodzice uważają, iż technologie cyfrowe wspierają edukację dzieci i młodzieży - 48\% stanowią uzupełnienie zajęć tradycyjnych, $45 \%$ - wspierają przebieg zajęć tradycyjnych. Rodzice wspierają wykorzystanie technologii cyfrowych $\mathrm{w}$ edukacji, nie boją się faktu, iż ich dzieci poza korzystaniem z tradycyjnych (dobrze znanych rodzicom) pomocy oraz narzędzi dydaktycznych korzystają również z narzędzi cyfrowych. Rodzice traktują jednak nauczanie w wykorzystaniem cyfrowych technologii nie jako główny, wiodący nurt edukacyjny, ale jako uzupełnienie, wsparcie zajęć tradycyj- 
nych. Bardzo wąska część rodziców uważa, iż technologie cyfrowe/nauczanie cyfrowe wypierają lub mogłoby wyprzeć tradycyjne formy i metody edukacyjne. Rodzice widzą możliwość wykorzystania cyfrowych technologii edukacyjnych jako wsparcia w kształceniu swoich dzieci zarówno w szkole, jak i w domu. W ogólnym nastawieniu rodziców do wykorzystania technologii cyfrowych w edukacji ich dzieci nie pojawiają się różnice, jeśli chodzi o poziom edukacyjny (podobnie sytuację oceniają zarówno rodzice uczniów szkół podstawowych, gimnazjów jak i szkół zawodowych, liceów i techników). Rodzice uważają, iż technologie cyfrowe zwiększają zarówno efektywność, jak i atrakcyjność zajęć przy czym znacznie wyżej oceniają ich wpływ na atrakcyjność zajęć. Bardzo wysoko rodzice oceniają wpływ wykorzystania technologii cyfrowych na możliwość nauki z dowolnego miejsca w dowolnym tempie oraz indywidualizację procesu kształcenia dzieci i młodzieży.

\section{W jaki sposób technologie cyfrowe mogą wspierać edukację dziecka?}

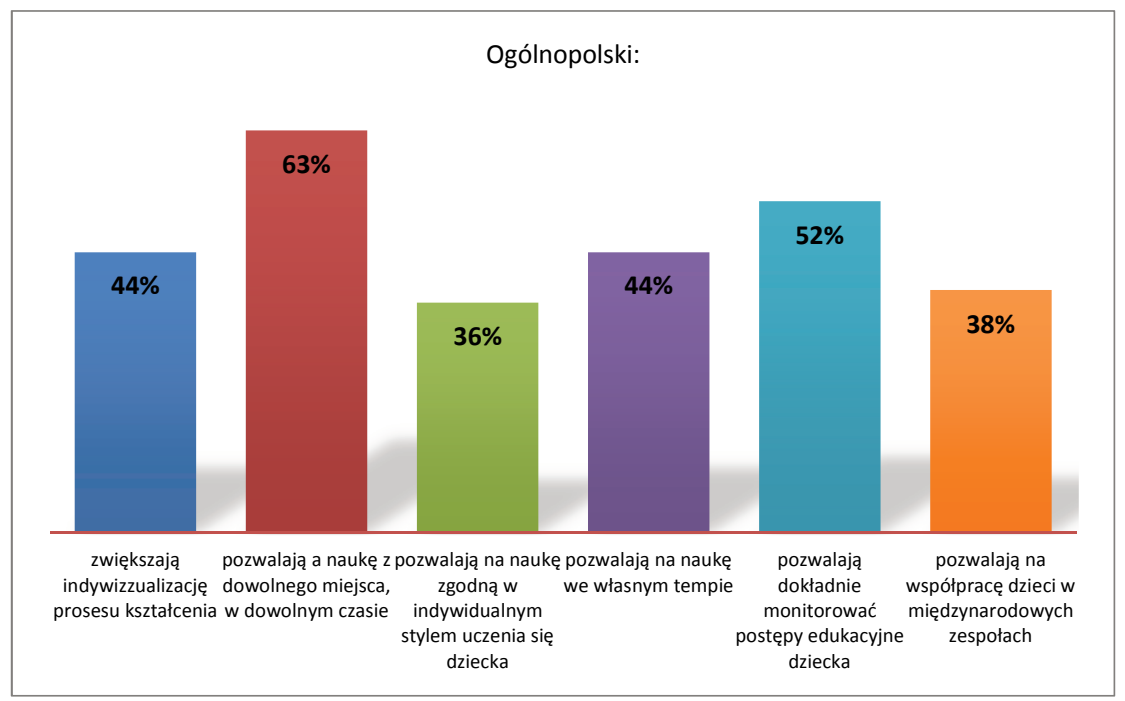

Rys. 4. Rola technologii cyfrowych w procesie nauczania Źródło: Raport Polska szkoła w dobie cyfryzacji. Diagnoza 2017 


\section{Wyposażenie pracowni komputerowych}

Nauczyciele deklarują, że prawie wszystkie pracownie komputerowe wyposażone są w komputer (96\%). 75\% pracowni wyposażonych jest w rzutnik, 45\% w tablice interaktywną, tylko niecałe 5\% w tablety. Niezwykle rzadko pracownie wyposażone są w specjalistyczny sprzęt tj. roboty, klocki do nauki programowania, czujniki, mapy interaktywne, wizualizery, okulary do rozszerzonej rzeczywistości itp. Wyposażenie pracowni zdaniem nauczycieli jest na poziomie dobrym (41\%) i bardzo dobrym (14\%). 30\% pedagogów opisuje je na poziomie przeciętnym.

W jakie w narzędzia technologiczne wyposażona jest Twoja pracownia przedmiotowa?

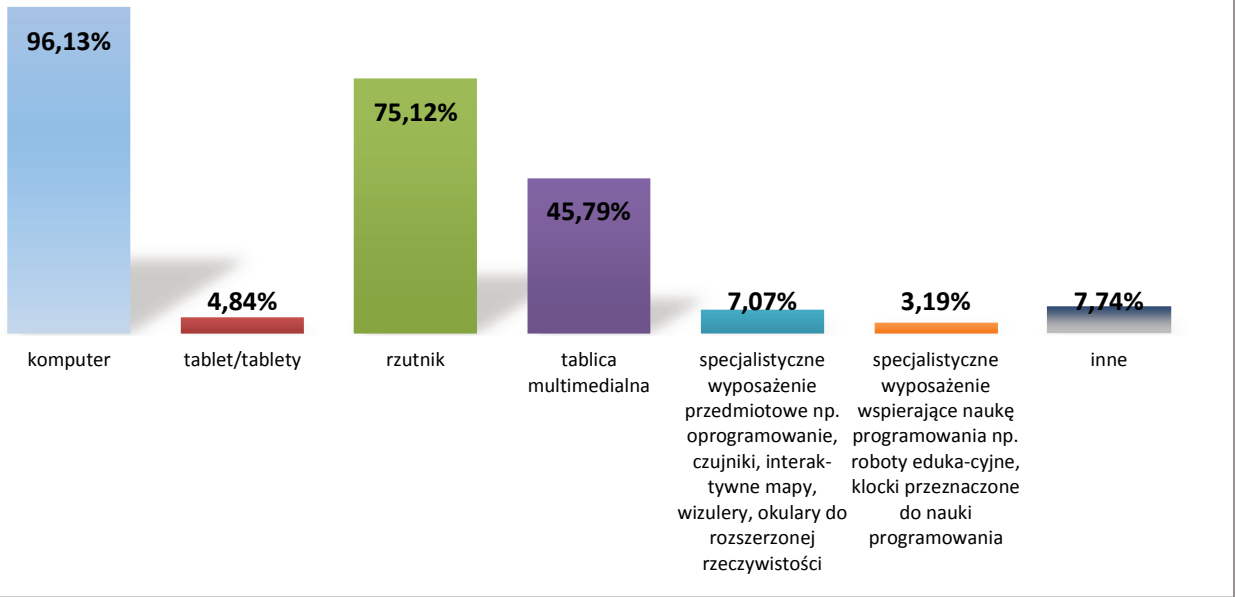

Rys. 5. Narzędzia technologiczne w szkole

Źródło: Raport Polska szkoła w dobie cyfryzacji. Diagnoza 2017

Z kolei rodzice, wskazując narzędzia technologiczne adekwatne w ich opinii do użycia w edukacji, wskazują rozwiązania/narzędzia dobrze im znane, takie które często sami stosują w swojej pracy. 
Za narzędzia najpopularniejsze rodzice uważają komputery oraz tablice multimedialne, dużo niżej oceniają wykorzystanie w edukacji tabletów, smartfonów, narzędzia do programowania. Wynik ten wskazuje na fakt, iż rodzice nie rozumieją zasad wykorzystania poszczególnych narzędzi w edukacji oraz korzyści płynących z wykorzystania poszczególnych narzędzi. Bardzo ciekawe wskaźniki to wskaźniki wykorzystania podręczników elektronicznych oraz cyfrowych zasobów edukacyjnych. Bardzo optymistycznym wydaje się fakt, iż większy potencjał widzą respondenci badania w wykorzystaniu cyfrowych zasobów niż typowych e-podręczników. Rodzice uważają również, iż zastosowanie technologii cyfrowych w edukacji zwiększa zaangażowanie uczniów w proces edukacyjny. Tylko nieliczne głosy oceniają nisko potencjał technologii cyfrowych w zwiększaniu zaangażowania uczniów w proces edukacyjny, szeroko rozumiany rozwój.

\section{Dostęp do internetu}

Zadawalającym aspektem zmiany w polskiej szkole jest dostęp do internetu $\mathrm{w}$ większości przypadków oceniany jest na poziomie dobrym (42\%) i bardzo dobrym (27\%). Większość uczniów korzysta na terenie szkoły z własnego dostępu do internetu (52\% badanych). $27 \%$ ankietowanych nie ma w szkole dostępu do internetu. $23 \%$ korzysta ze szkolnej sieci bezprzewodowej. Bezprzewodowy internet najlepiej funkcjonuje $\mathrm{w}$ technikach (33\%), najgorzej w gimnazjach (20\%). W gimnazjum odsetek ankietowanych deklarujących całkowity brak dostępu do bezprzewodowego internetu. Większość uczniów ocenia dostęp do internetu w szkole jako przeciętny (32\%). $30 \%$ twierdzi, że jest on bardzo dobry lub dobry. 38\% ocenia go jako slaby i bardzo słaby. Najsłabiej dostęp do internetu oceniają uczniowie w szkole zawodowej (22\%), najlepiej w technikum (35\%).

Dostęp do bezprzewodowego internetu większość ocenia jako przeciętny lub słaby (58\%). 8\% jako bardzo dobry, $12 \%$ jako bardzo słaby. Najsłabiej dostęp do bezprzewodowego internetu oceniają uczniowie szkół zawodowych i gimnazjów (15\% uczniów z tych placówek twierdzi, że jest bardzo słaby). 
Jak oceniasz dostęp do sieci internet dla uczniów w Twojej szkole?

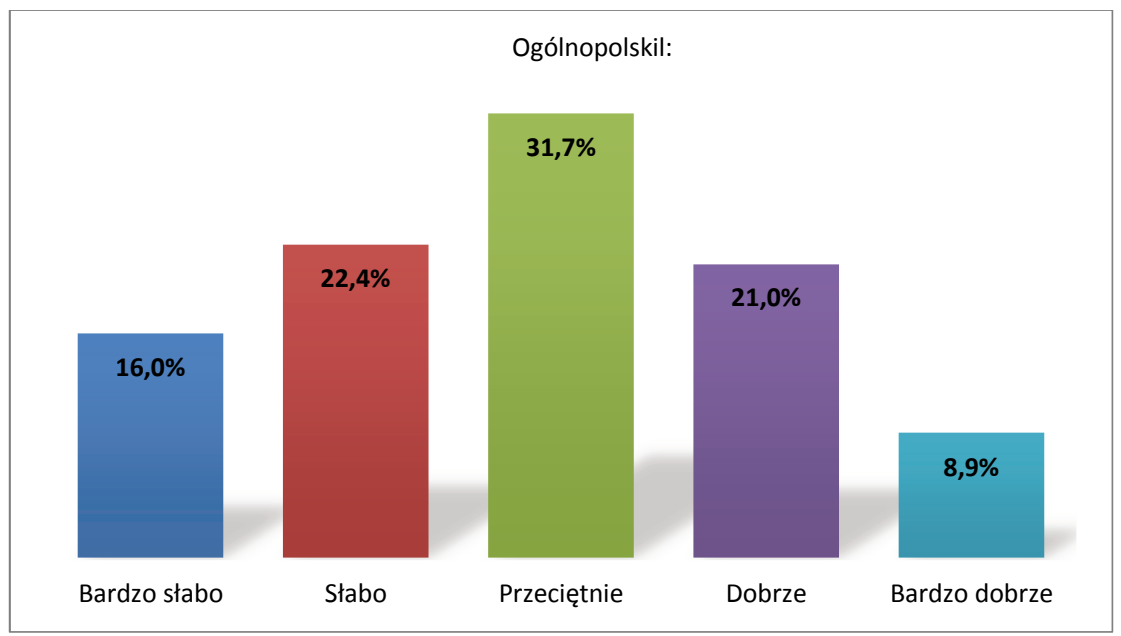

Rys. 6. Dostęp do internetu w szkole

Źródło: Raport Polska szkoła w dobie cyfryzacji. Diagnoza 2017

Nauczyciele znacznie przychylniej niż uczniowie odnoszą się do wyposażenia szkół $\mathrm{w}$ dostęp do internetu. Większość nauczyciele dostęp do sieci ocenia na poziomie dobrym (42\%) i bardzo dobrym $(27 \%)$. Co trzeci z respondentów (33\% wskazań) może też korzystać $\mathrm{z}$ bezprzewodowego internetu dostępnego dla uczniów i nauczycieli.

Duże znaczenie dla pełnego wykorzystania potencjału cyfrowej edukacji ma projekt OSE. Jak pokazują badania Ministerstwa Cyfryzacji, obecnie tylko 10\% szkół i placówek oświatowych w Polsce ma dostęp do internetu o parametrach, które umożliwiają wykorzystywanie go do procesów dydaktycznych. Zapewnienie wszystkim placówkom szkolnym szybkiego i bezpiecznego internetu to wyrównywanie szans edukacyjnych i inwestycja w przyszłość.

Wdrożenie rządowego projektu OSE stanowić będzie cywilizacyjną zmianę dla polskich szkół. Bezpieczny internet w każdej szkole to szansa na wyrównanie dostępu do wiedzy, rozwój nowych form kształcenia oraz zdobywanie kompetencji, zarówno przez 
uczniów, jak i nauczycieli. Projekt OSE powstał dzięki staraniom Ministerstwa Cyfryzacji, a jego Operatorem jest NASK Państwowy Instytut Badawczy 4 . Z pewnością kolejne diagnozy cyfryzacji po projektu OSE wykażą znaczące zmiany w tym obszarze cyfryzacji.

\section{Multimedialne narzędzia w dydaktyce}

Najczęściej stosowanym multimedialnym narzędziem jest komputer (34\% ankietowanych udzieliło takiej odpowiedzi). Na drugim miejscu uplasowała się tablica multimedialna (26\%), na trzecim smartfon (18\%). Tylko 2\% uczniów deklaruje wykorzystanie tabletów w szkole. Interfejsy pomiarowe, klocki do nauki programowania, roboty użytkowane są w placówkach edukacyjnych przez około $1 \%$ respondentów.

\section{Z jakiego sprzętu korzystasz w czasie zajęć lekcyjnych?}

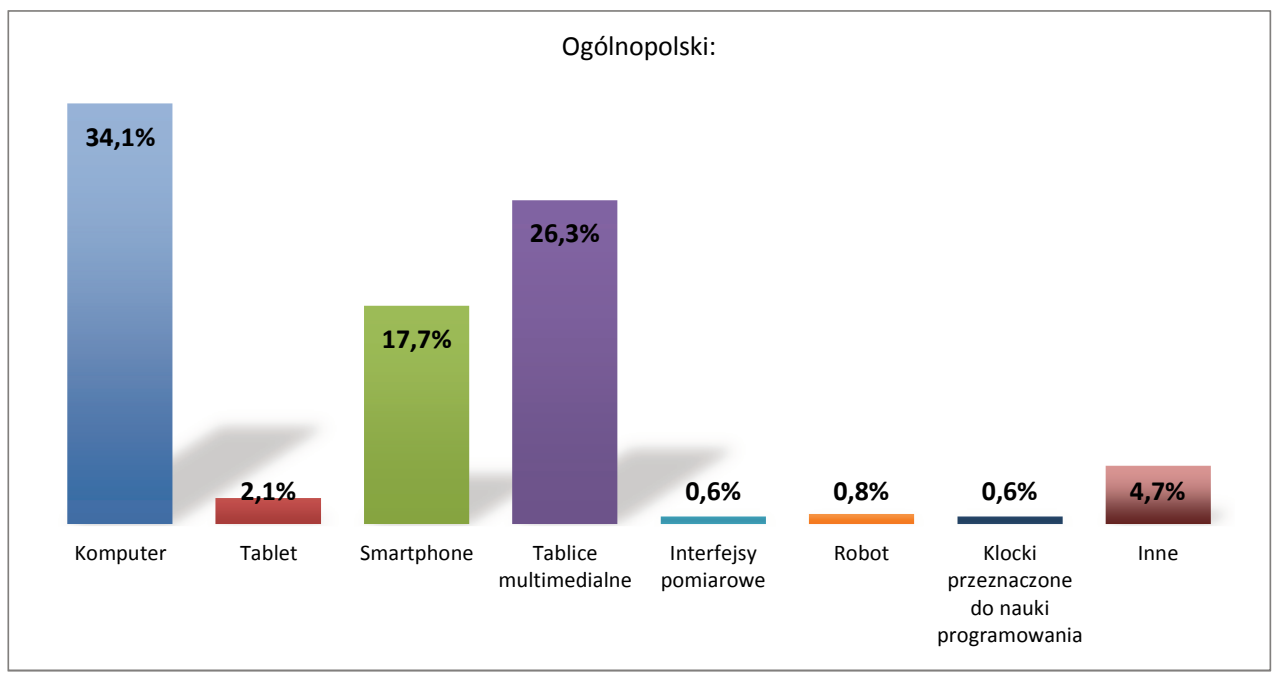

Rys. 7. Wykorzystanie sprzętu na zajęciach lekcyjnych

Źródło: Raport Polska szkoła w dobie cyfryzacji. Diagnoza 2017

${ }^{4}$ https:/ /ose.gov.pl [dostęp: 20.12.2018]. 
Nauczyciele deklarują, że podczas procesu dydaktycznego najczęściej korzystają z komputerów (99\% wskazań) i tablic interaktywnych (56\%). Rzadziej ze smartfonów (30\%) i tabletów (12\%). Najmniej wskazań otrzymały interfejsy pomiarowe, roboty, klocki do programowania (2-3\%). Pozytywnym wnioskiem z przeprowadzonego sondażu jest fakt wykorzystywania przez nauczycieli wszystkich wymienionych cyfrowych technologii edukacyjnych. Jednak najczęściej podczas zajęć lekcyjnych nauczyciele wykorzystują prezentację multimedialną $(87,7 \%)$ i angażują uczniów $(56,7 \%)$ do ich tworzenia lub przygotowywania cyfrowych materiałów $\mathrm{w}$ domu. Często korzystają też z tablicy interaktywnej (48\%), wykorzystując materiały multimedialne i ćwiczenia interaktywne. Można zatem przypuszczać, że zajęcia mają tradycyjną strukturę, organizację i przebieg, gdzie aktywniejszy jest nauczyciel, który przekazuje wiedzę lub ocenia wiedzę swoich uczniów (wykorzystanie quizów interaktywnych na poziomie $41 \%$ ). Nawet gry edukacyjne wskazane zostały tylko na poziomie $20 \%$.

Zdaniem uczniów na lekcjach wykorzystuje się głównie prezentacje multimedialne $(17 \%)$, filmy i animacje $(15 \%)$, tabele, ilustracje $(14 \%)$, artykuły, informacje z internetu (13\%), podręczniki cyfrowe $(10 \%)$, materiały audio $(7 \%)$, gry, quizy $(7 \%)$. Tylko $3 \%$ uczniów korzysta z aplikacji mobilnych i e-booków.

Poziom wykorzystania oraz celowość wykorzystania materiałów multimedialnych przez nauczycieli pozostawia zatem wiele wątpliwości. Lekcja prowadzona z wykorzystanie komputera, rzutnika oraz prezentacji multimedialnej jest mało efektywna, powiela tradycyjny podające metody edukacji. Kwestia efektywnych modeli lekcji z wykorzystanie cyfrowych zasobów edukacyjnych pozostawia jeszcze bardzo dużo do życzenia.

\section{Podsumowanie}

Jak wynika z przedstawionych danych, poziom przygotowania polskich szkół do wdrożenia innowacyjnego kształcenia jest niski. Zarówno twarde parametry, takie jak poziom wykorzystania infra- 
struktury sieciowej czy sprzętu, jak i miękkie wskaźniki, takie jak poziom kompetencji cyfrowych, świadczą o tym, iż polska szkoła jest na początku drogi wdrożenia innowacyjnego kształcenia bazującego na narzędzia cyfrowe. Szczególnie istotnym elementem procesu cyfryzacji polskich szkół pozostają kompetencje nauczycieli. Niestety brak konieczności rozwoju kompetencji cyfrowych, niedostateczne przygotowanie oferty dydaktycznej dla nauczycieli w zakresie podnoszenia kompetencji cyfrowych oraz celowego prowadzania innowacyjnych, przemyślanych zajęć. Przed polską szkołą jeszcze długa droga cyfryzacji, droga, która zaprowadzi nie tylko do biernego wdrożenia sprzętu w szkołach, lecz także zbuduje umiejętność kreatywnego budowania zajęć dydaktycznych w silnej korelacji z kompetencjami przyszłości. Droga ta nie jest trudna w kontekście technologicznym, lecz bardzo trudna w kontekście mentalnym trudno bowiem łamać utarte schematy, poszukiwać nowych rozwiązań, postrzegać rozwój uczniów jako pracowników przyszłości.

\section{Bibliografia}

Bednarek J., Multimedia w kształceniu, Wydawnictwo Naukowe PWN, Warszawa 2006. Clarke A., E-learning. Nauka na odlegtość, Wydawnictwa Komunikacji i Łączności, Warszawa 2007.

Hamblin A., Evoluation and Control of Training, McGraw-Hill, Maidenhead 1974.

Kwiatkowska I., E-learning i nowe media w polityce Unii Europejskiej, „Edukacja Medialna" 2003, nr 3, s. 217-231.

Kwiatkowska I., Wirtualne uniwersytety, „Edukacja Medialna” 2003, nr 2, s. 22-29.

MonsterPolska.pl, Kompetencje przyszłości - to warto umieć, żeby czuć się bezpiecznie na rynku pracy, https://sukcespisanyszminka.pl/kompetencje-przyszlosci/ [dostęp: 20.12.2018], https://ose.gov.pl [dostęp: 20.12.2018].

Plebańska M., Charakterystyka nauczania na odlegtość [w:] O kompetencjach kluczowych, e-learningu i metodzie projektów, red. M.P.A. Okońska-Walkowicz, WSiP, Warszawa 2009.

Plebańska M., E-Learning, Tajniki edukacji na odlegtość, CH Beck, Warszawa 2011.

Plebańska M., STEAM - edukacja przysztości, „Mazowiecki Kwartalnik Edukacyjny Meritum" 2018, nr 4(51), s. 2-7.

Vitorović N., Miejsce pracy w 2020 r.: Jak innowacyjne firmy przyciagaja dziś pracowników jutra, wspieraja ich rozwój i zatrzymują, http://www.pi.gov.pl/PARP/chap ter_86199.asp?soid=C8A49387D2884B7B80AA8E3099BE0199 [dostęp: 20.12.2018]. 